\title{
Optimization of mechanical properties in foamcrete reinforced with raw oil palm empty fruit bunch (EFB) fiber
}

\author{
Mazlina Musa ${ }^{1}$, Md Azree Othuman Mydin ${ }^{1, *}$, and Abdul Naser Abdul Ghani ${ }^{1}$ \\ ${ }^{1}$ School of Housing, Building and Planning, Universiti Sains Malaysia, 11800, Penang, Malaysia
}

\begin{abstract}
As Malaysia currently heading to biotechnology hub, it is expected that billions tons of palm oil by-products will be produced annually and normally been treated as waste disposal. A large amount of agricultural waste produced in the processing of palm oil is one of the main contributors to the environmental problem. This paper presents an experimental study on the development of the lightweight foamcrete with the inclusion of raw oil palm empty fruit bunch (EFB) fiber. EFB fiber has potential to be developed as alternative fibers in fiber reinforcing concrete. The study was focused on 4 mechanical property parameters which were axial compressive strength, flexural strength, splitting tensile strength and performance index. Three densities of lightweight foamcrete of 800,1100 and $1400 \mathrm{~kg} / \mathrm{m}^{3}$ were cast and tested. The ratio of cement, sand and water used in this study was 1:1.5:0.45. EFB fibers were used as additives at $0.15 \%, 0.30 \%, 0.45 \%, 0.60 \%$ and $0.75 \%$ by volume of the total mix. The results obtained from the experiments had indicated that the flexural strength of foamcrete reinforced with raw oil palm EFB fiber at different percentages for 800,1100 and $1400 \mathrm{~kg} / \mathrm{m}^{3}$ densities correspondingly. For all densities, $0.45 \%$ EFB fiber reinforced foamcrete contributed to highest flexural strength. Same pattern can be observed on the compressive and splitting tensile strengths. EFB fiber aid in precluding the promulgation of cracks in the plastic state when load was applied. When the lightweight foamed concrete expands under axial compression and splitting tensile loads which will lead to cracking, the crack has a restricted distance over which it can spread before reaching the EFB fiber, preventing the crack from growing further. EFB fibers which were randomly dispersed in the mix provide three dimension reinforcement compared to the traditional rebar which provides two dimension reinforcement.
\end{abstract}

\section{Introduction}

Malaysia is one of the biggest producers of oil palm in the world. The oil palm industry in Malaysia is over half of the world's total palm oil today, since Malaysia produces about 17.7 million tons of palm oil on 4.5 million hectares of land made agricultural waste from oil palm is high [1]. There are at least 417 productive palm oil extraction mills nationwide

\footnotetext{
*Corresponding author: azree@usm.my
} 
[2,3] and more than 22.4 million tons of the empty fruit bunch (EFB) as solid waste (green weight) was generate by these mills yearly $[4,5]$. During the palm oil, a considerable amount of solid waste in the form of fibers, EFB, kernel shells are produced [6,7]. Nevertheless, these wastes are basically disposed without any economic return $[8,9]$.

Oil palm fiber either from trunk of empty fruit bunch (EFB) is a unique reinforcing material as it is renewable, non-hazardous and readily available at low cost due to established technology to extract the fiber compared with other commercially fibers [10]. However, only small percentages of this fiber are a useful products and the rest is either worst, left to rot, burnt or being the pollution to the environment [11,12]. A research programmed was investigating some possible uses of this fiber for housing application and the results show that by incorporate fibers into the cement matrix can provide some reinforcement for the concrete products and increase the tensile strength by delaying the growth of cracks [13]. According to research stated that the beneficial effect of fibers in concrete is at low fiber content of $1 \%$ to $3 \%$ [14].

\section{Constituent Materials and Design Mix}

\subsection{Materials}

Type 1 Portland cement (OPC) produced by YTL Cement Bhd was used which comply to BS 12:1996 standard. Locally available fine aggregate was used which was supplied by a local distributor. A sieve analysis has been carried out to identify the suitability of the sand to be used according to British Standard BS 882: 1992. A protein based foaming agent namely, Noraite PA-1 was chosen to be used in this study. In addition clean water is used for mixing and curing shall be clean and free from any debris and other organic materials. This is because if the water used is not clean, it can affect the performance of concrete. Otherwise, cleaned water is needed to mix together with the protein to create good foam agent that free from debris. Water to cement ratio that been used for this research is 0.45 as it had achieved reasonable workability of foamed concrete. Raw oil palm empty fruit bunch (EFB) fibers were used as additives at $0.15 \%, 0.30 \%, 0.45 \%, 0.60 \%$ and $0.75 \%$ by volume of the total mix. The main components of oil palm EFB fiber, elemental analysis of oil palm EFB fiber properties and proximate analysis of oil palm empty fruit bunches fiber contents are shown in Table 1, Table 2 and Table 3 respectively. On the other hand, Figure 1 shows the surface of oil palm empty fruit bunches fiber surface using the scanning electron micrograph. From Figure 1, it can be seen that the surface of the oil palm empty fruit bunches fiber is rough and porous.

Table 1: Main components of oil palm empty fruit bunches fiber.

\begin{tabular}{|c|c|}
\hline Component & Percentage $(\mathbf{m f} \mathbf{w t} \%)$ \\
\hline Cellulose & 59.7 \\
\hline Hemicellulose & 22.2 \\
\hline Lignin & 18.1 \\
\hline
\end{tabular}


Table 2: Elemental analysis of oil palm empty fruit bunches fiber properties.

\begin{tabular}{|c|c|}
\hline Element & Percentage (mf wt\%) \\
\hline Carbon & 49.7 \\
\hline Hydrogen & 6.48 \\
\hline Nitrogen & 0.7 \\
\hline Sulphur & 0.2 \\
\hline Oxygen & 37.87 \\
\hline $\mathrm{K}$ & 2 \\
\hline $\mathrm{K}_{2} \mathrm{O}$ & 3.05 \\
\hline
\end{tabular}

Table 3: Proximate analysis of oil palm empty fruit bunches fiber contents.

\begin{tabular}{|c|c|}
\hline Content & Percentage (mf wt\%) \\
\hline Moisture & 7.83 \\
\hline Volatiles & 76.61 \\
\hline Ash & 5.78 \\
\hline Fixed Carbon & 9.78 \\
\hline
\end{tabular}
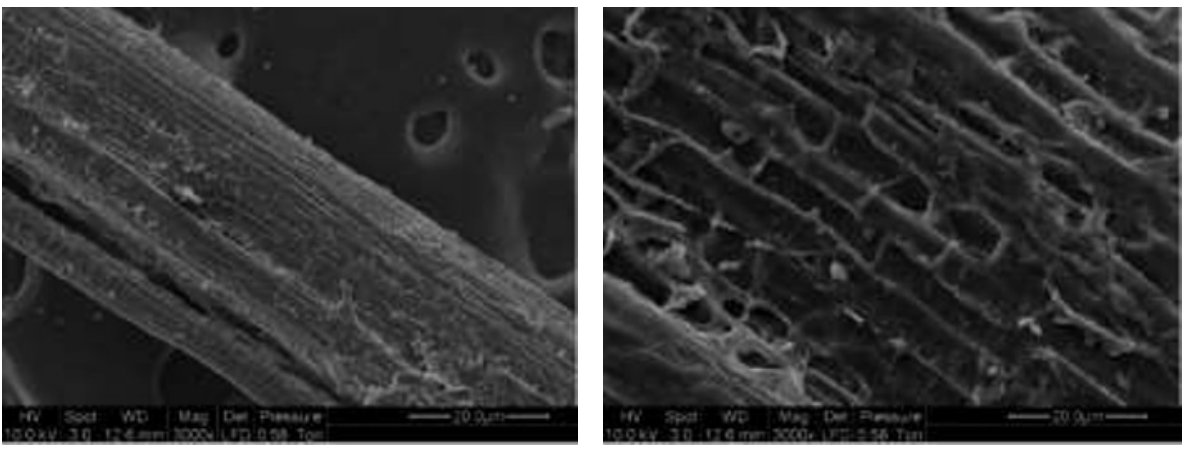

Fig. 1. SEM micrographs of oil palm empty fruit bunches fiber surface.

\subsection{Design Mix}

There were total of 18 mixes were prepared for this study. The mix design proportions for $800 \mathrm{~kg} / \mathrm{m}^{3}, 1100 \mathrm{~kg} / \mathrm{m}^{3}$ and $1400 \mathrm{~kg} / \mathrm{m}^{3}$ is shown in Table 4 . Raw oil palm empty fruit bunch (EFB) fibers were used as additives at $0.15 \%, 0.30 \%, 0.45 \%, 0.60 \%$ and $0.75 \%$ by volume of the total mix. The proportion of mortar was cement, sand and water in the ratio of 1:1.5:0.45. Water to cement ratio that been used for this research is 0.45 as it has attained practical workability of foamcrete.

Table 4. Design mix proportions.

\begin{tabular}{|c|c|c|c|c|c|}
\hline Sample & $\begin{array}{c}\text { Mix Density } \\
\left(\mathbf{k g} / \mathbf{m}^{\mathbf{3}}\right)\end{array}$ & $\begin{array}{c}\text { Mix Ratio } \\
(\mathbf{S : C : W})\end{array}$ & Cement $\mathbf{( k g )}$ & $\begin{array}{c}\text { Fine } \\
\text { Aggregates (kg) }\end{array}$ & Water $(\mathbf{k g})$ \\
\hline Control & 800 & $1: 1: 5: 0.45$ & 15.12 & 22.68 & 6.81 \\
\hline $0.15 \%$ EFB & 800 & $1: 1: 5: 0.45$ & 15.12 & 22.68 & 6.81 \\
\hline $0.30 \%$ EFB & 800 & $1: 1: 5: 0.45$ & 15.12 & 22.68 & 6.81 \\
\hline $0.45 \%$ EFB & 800 & $1: 1: 5: 0.45$ & 15.12 & 22.68 & 6.81 \\
\hline $0.60 \%$ EFB & 800 & $1: 1: 5: 0.45$ & 15.12 & 22.68 & 6.81 \\
\hline $0.75 \%$ EFB & 800 & $1: 1: 5: 0.45$ & 15.12 & 22.68 & 6.81 \\
\hline Control & 1100 & $1: 1: 5: 0.45$ & 20.54 & 30.81 & 9.24 \\
\hline $0.15 \%$ EFB & 1100 & $1: 1: 5: 0.45$ & 20.54 & 30.81 & 9.24 \\
\hline $0.30 \%$ EFB & 1100 & $1: 1: 5: 0.45$ & 20.54 & 30.81 & 9.24 \\
\hline
\end{tabular}




\begin{tabular}{|c|c|c|c|c|c|}
\hline $0.45 \%$ EFB & 1100 & $1: 1: 5: 0.45$ & 20.54 & 30.81 & 9.24 \\
\hline $0.60 \%$ EFB & 1100 & $1: 1: 5: 0.45$ & 20.54 & 30.81 & 9.24 \\
\hline $0.75 \%$ EFB & 1100 & $1: 1: 5: 0.45$ & 20.54 & 30.81 & 9.24 \\
\hline Control & 1400 & $1: 1: 5: 0.45$ & 25.96 & 38.93 & 11.68 \\
\hline $0.15 \%$ EFB & 1400 & $1: 1: 5: 0.45$ & 25.96 & 38.93 & 11.68 \\
\hline $0.30 \%$ EFB & 1400 & $1: 1: 5: 0.45$ & 25.96 & 38.93 & 11.68 \\
\hline $0.45 \%$ EFB & 1400 & $1: 1: 5: 0.45$ & 25.96 & 38.93 & 11.68 \\
\hline $0.60 \%$ EFB & 1400 & $1: 1: 5: 0.45$ & 25.96 & 38.93 & 11.68 \\
\hline $0.75 \%$ EFB & 1400 & $1: 1: 5: 0.45$ & 25.96 & 38.93 & 11.68 \\
\hline
\end{tabular}

\section{Experimental Setup}

The compressive strength was carried in compliance with BS EN 12390-3:2009. Cube specimen size of $100 \mathrm{~mm} \times 100 \mathrm{~mm} \times 100 \mathrm{~mm}$ was used to determine the axial compressive strength. The flexural strength of lightweight foamed concrete was established using GoTech GT-7001-C10 Universal Testing Machine. The test was carried out according to procedure in it was conducted according to BS EN 1521:1997. The specimen size is $100 \mathrm{~mm} \times 100 \mathrm{~mm} \times 500 \mathrm{~mm}$ with the result taken at $7^{\text {th }}$ and $28^{\text {th }}$ day of age. The splitting tensile strength was carried in compliance with ASTM C496. Specimens tested in the tensile splitting test were covered up to the $7^{\text {th }}, 28^{\text {th }}$ and $60^{\text {th }}$ day of age. The specimen size used was $100 \mathrm{~mm}$ in diameter and $200 \mathrm{~mm}$ in height cylinder. An axial load with a loading rate of $0.2 \mathrm{~N} / \mathrm{sec}$ was applied to cylindrical specimen until failure occurred. Mean value acquired from 3 cylinders was then taken as splitting tensile strength for each lightweight foamed concrete mix.

\section{Experimental Results and Discussion}

\subsection{Flexural Strength}

Figures 2, 3 and 4 visualizes the flexural strength of foamcrete reinforced with raw oil palm Empty Fruit Bunch (EFB) fiber at different percentages for $800 \mathrm{~kg} / \mathrm{m}^{3}, 1100 \mathrm{~kg} / \mathrm{m}^{3}$ and $1400 \mathrm{~kg} / \mathrm{m}^{3}$ densities correspondingly. For all densities, $0.45 \%$ EFB fiber reinforced foamcrete contributed to highest flexural strength. For instance, for $800 \mathrm{~kg} / \mathrm{m}^{3}$ density, the flexural strength with $0.45 \%$ fiber inclusion by volume is $0.36 \mathrm{MPa}$ which is $40 \%$ higher than control foamcrete. The increased amount of EFB fiber added to the mix proportions (beyond $0.45 \%$ by volume) resulted in a lower flexural strength of fiber cement products. EFB fibre inclusion changes the flexural post-peak response at the load-deflection curves for the foamcrete specimens, which modifies the failure mode of specimen from brittle to ductile because of fibre bridging effect $[15,16]$. 


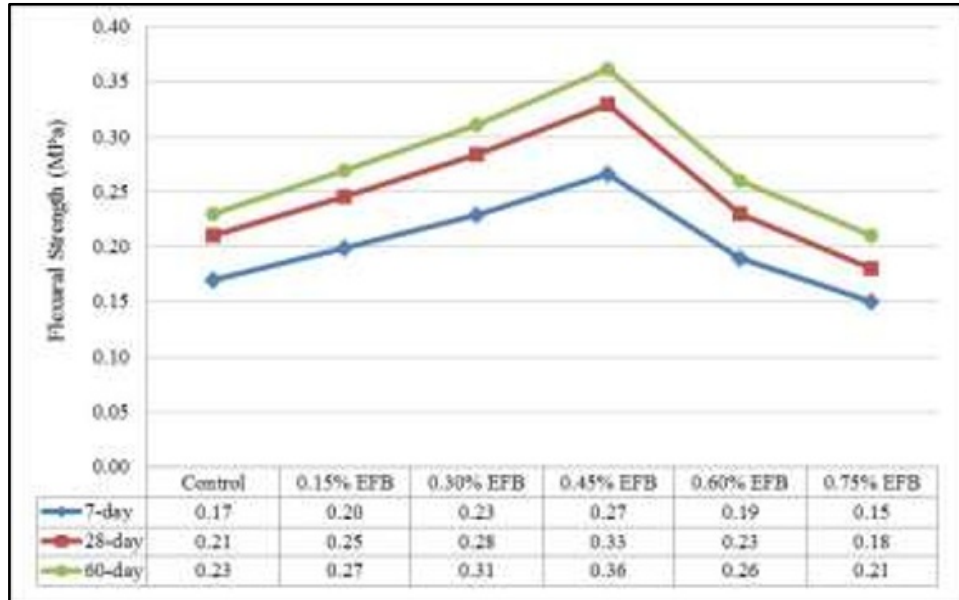

Fig. 2. Flexural strength results for $800 \mathrm{~kg} / \mathrm{m}^{3}$ density.

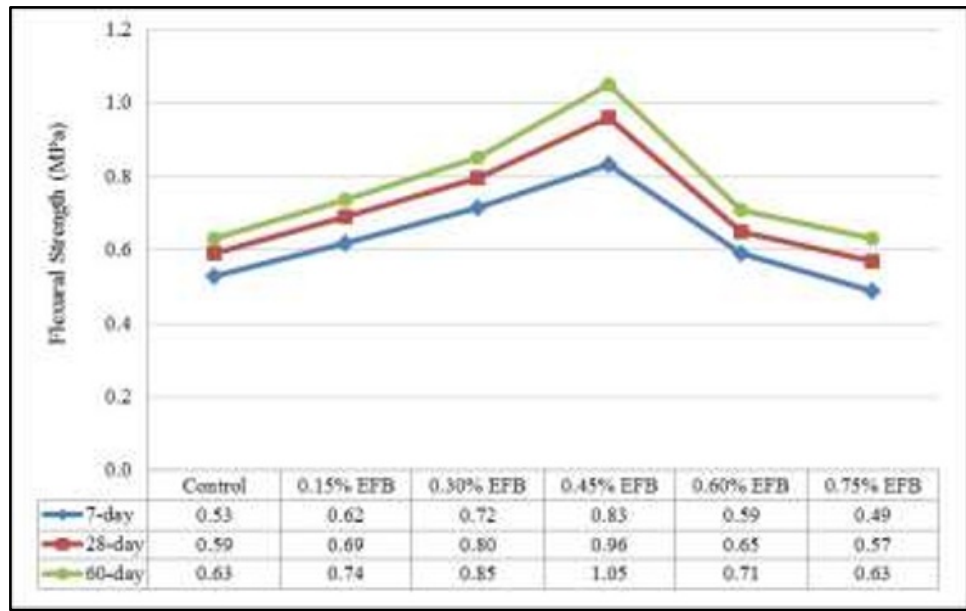

Fig. 3. Flexural strength results for $1100 \mathrm{~kg} / \mathrm{m}^{3}$ density.

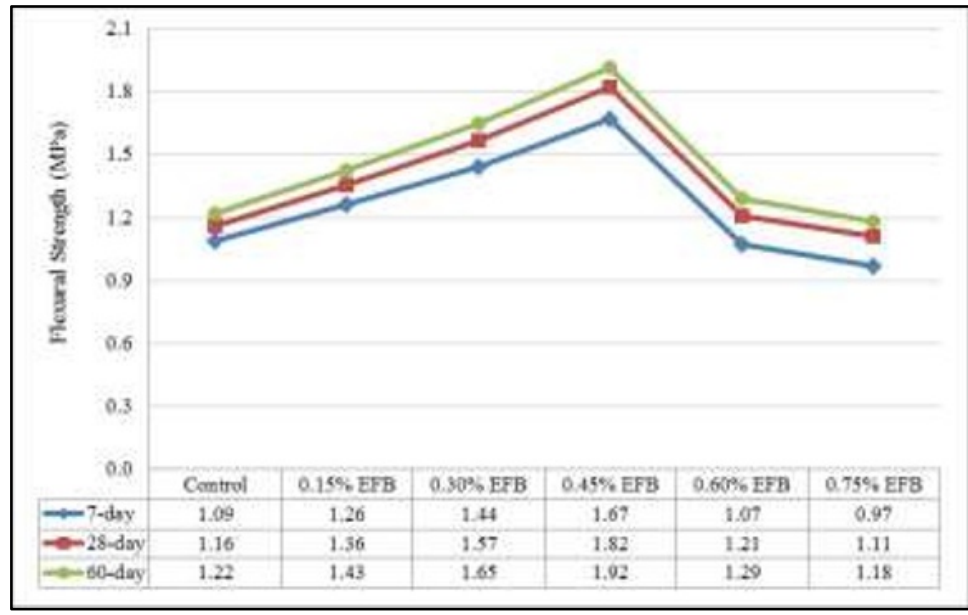

Fig. 4. Flexural strength results for $1400 \mathrm{~kg} / \mathrm{m}^{3}$ density. 


\subsection{Compressive Strength}

Figures 5, 6 and 7 demonstrates the axial compressive strength of foamcrete reinforced with raw oil palm Empty Fruit Bunch (EFB) fiber at different percentages for $800 \mathrm{~kg} / \mathrm{m}^{3}$, $1100 \mathrm{~kg} / \mathrm{m}^{3}$ and $1400 \mathrm{~kg} / \mathrm{m}^{3}$ densities in that order. As can be seen from these three figures, $0.45 \%$ EFB fiber reinforced foamcrete contributed to uppermost axial compressive strength. From these results, it can be concluded that inclusion of EFB fiber aid in precluding the promulgation of cracks in the plastic state in the cement matrix when load was applied. When the lightweight foamed concrete expands under axial compression load which will lead to cracking, the crack has a restricted distance over which it can spread before reaching the EFB fiber, preventing the crack from growing further [17]. EFB fibers which were randomly dispersed in the mix provide three dimension reinforcement compared to the traditional rebar which provides two dimension reinforcement [18].

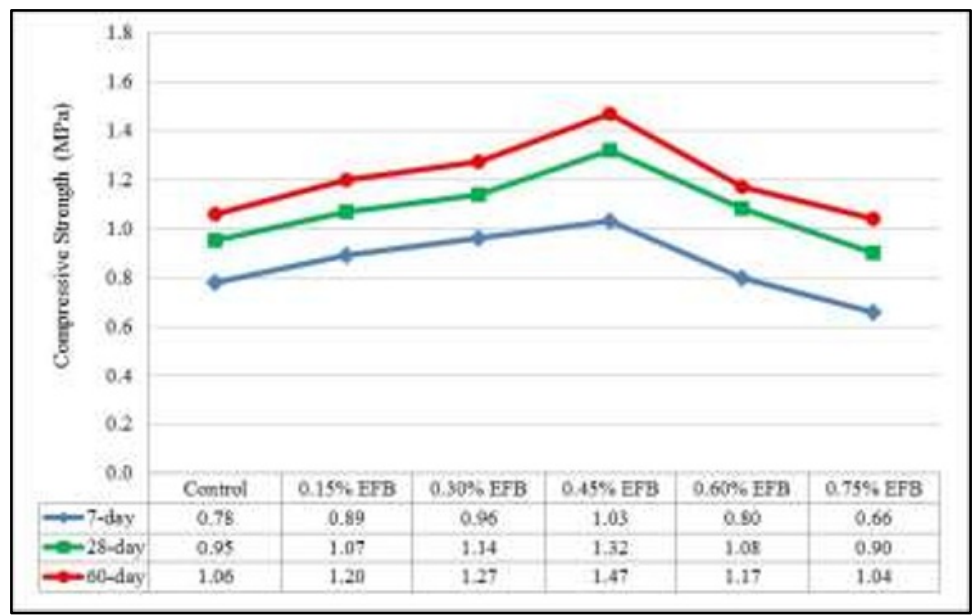

Fig. 5. Compressive strength results for $800 \mathrm{~kg} / \mathrm{m}^{3}$ density.

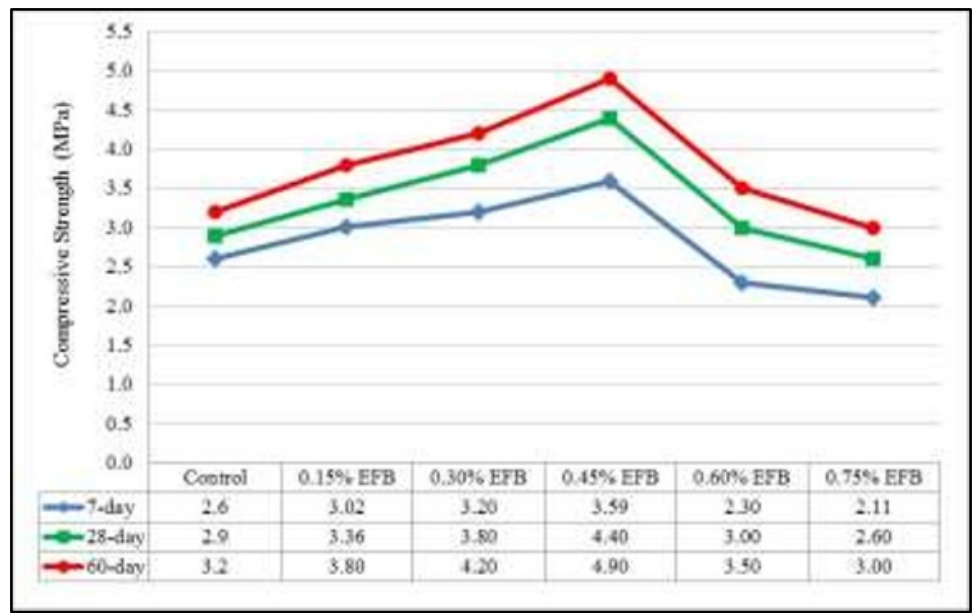

Fig. 6. Compressive strength results for $1100 \mathrm{~kg} / \mathrm{m}^{3}$ density. 


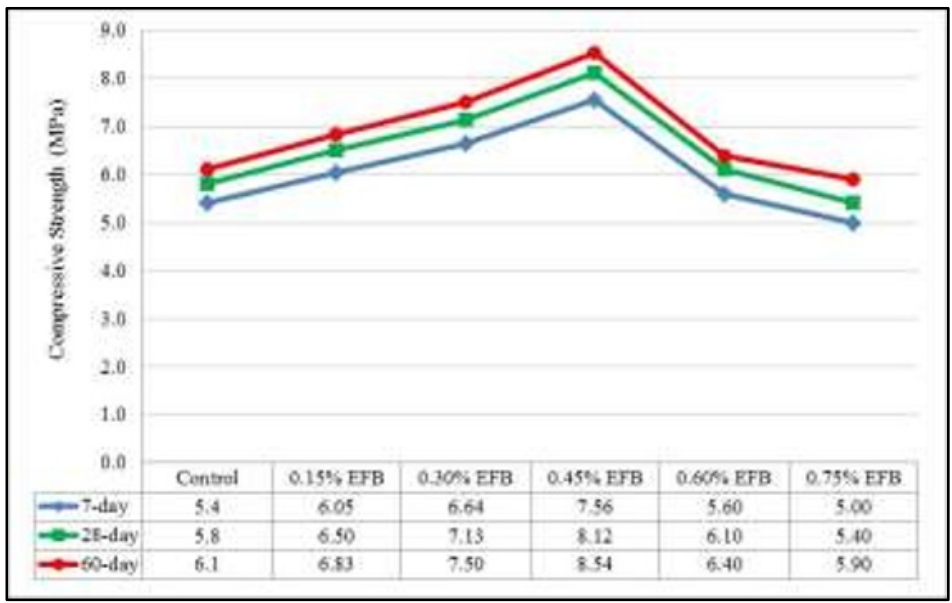

Fig. 7. Compressive strength results for $1400 \mathrm{~kg} / \mathrm{m}^{3}$ density.

\subsection{Performance Index}

Performance index is a parameter that used to acquire the strength of foamcrete per 1000 $\mathrm{kg} / \mathrm{m}^{3}$. In practice, it is difficult to produce entire specimen with the same density. Hence, performance index (PI) has been adopted in order to attain more precise and consistent results. The performance indexes of compressive strength for $800 \mathrm{~kg} / \mathrm{m}^{3}, 1100 \mathrm{~kg} / \mathrm{m}^{3}$ and $1400 \mathrm{~kg} / \mathrm{m}^{3}$ are shown in Figure 8, Figure 9 and Figure 10 respectively. Comparable trend was obtained by performance index, where the performance index is directly proportional to the specimen's curing age. As can be seen from Figure 8, the highest 60-day performance index was achieved by foamcrete mix with $0.45 \% \mathrm{EFB}$, which is $1.84 \mathrm{MPa}$ per $1000 \mathrm{~kg} / \mathrm{m}^{3}$. As for $1100 \mathrm{~kg} / \mathrm{m}^{3}$ density, the highest 60 -day performance index was achieved by foamcrete mix with $0.45 \% \mathrm{EFB}$, which is $4.45 \mathrm{MPa}$ per $1000 \mathrm{~kg} / \mathrm{m}^{3}$. On the other hand, highest 60 -day performance index achieved by $1400 \mathrm{~kg} / \mathrm{m}^{3}$ density is similar (foamcrete mix with $0.45 \% \mathrm{EFB}$ ) which is $6.10 \mathrm{MPa}$ per $1000 \mathrm{~kg} / \mathrm{m}^{3}$ ).

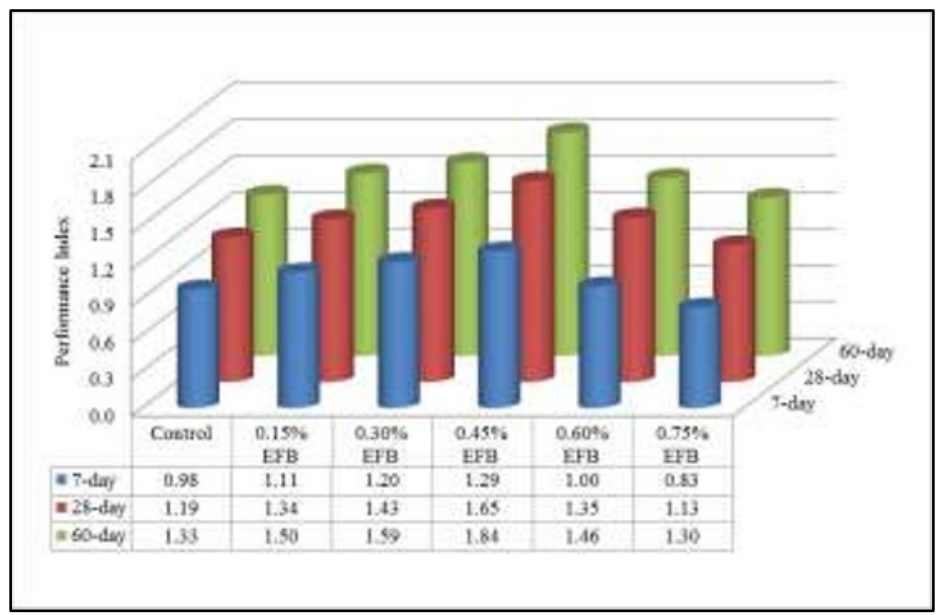

Fig. 8. Performance index of $800 \mathrm{~kg} / \mathrm{m}^{3}$ density mix. 


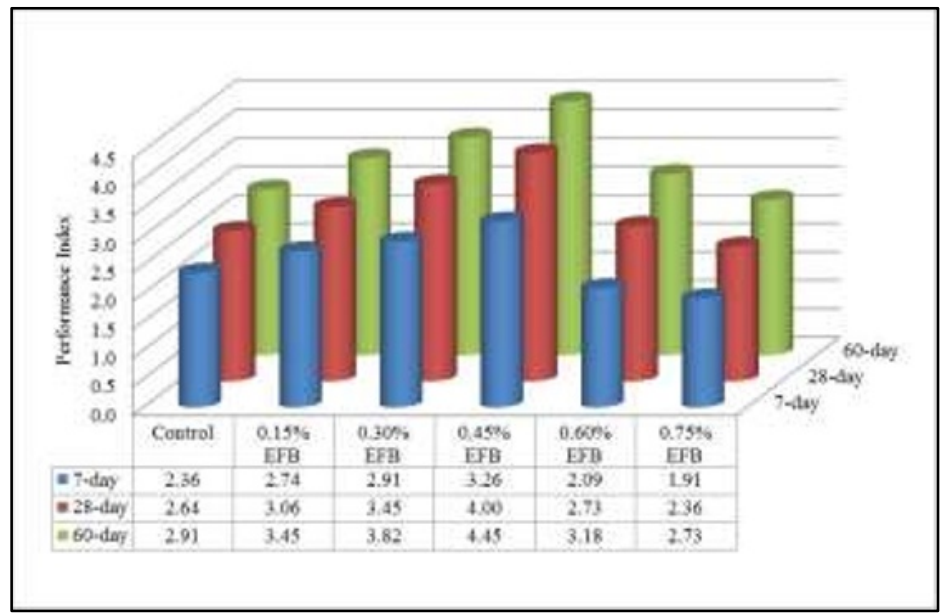

Fig. 9. Performance index of $1100 \mathrm{~kg} / \mathrm{m}^{3}$ density mix.

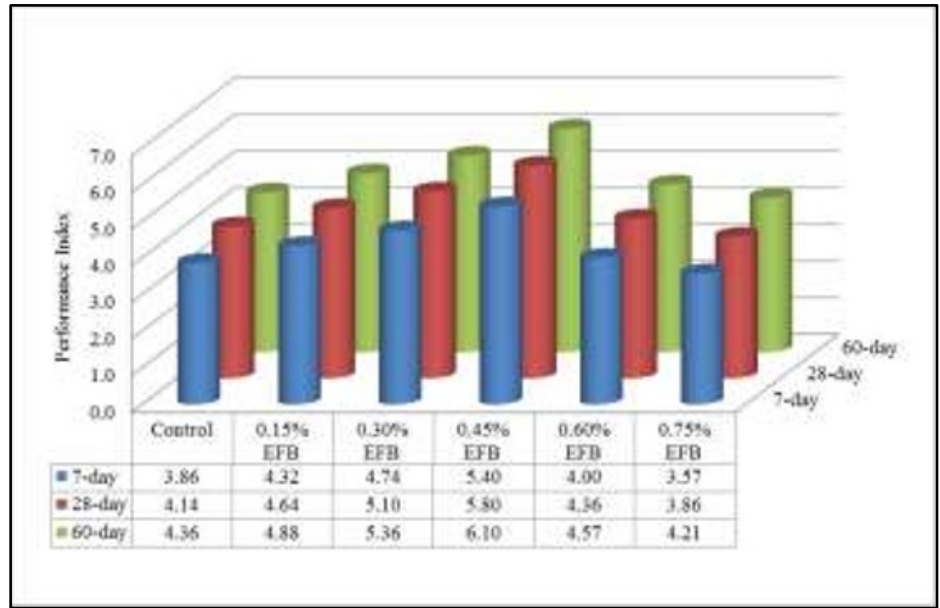

Fig. 10. Performance index of $1400 \mathrm{~kg} / \mathrm{m}^{3}$ density mix.

\section{Conclusion}

This paper presents an experimental study on the development of the lightweight foamcrete with the inclusion of raw oil palm empty fruit bunch (EFB) fiber. EFB fiber has potential to be developed as alternative fibers in fiber reinforcing concrete. The study reveals:

1. For all densities, $0.45 \%$ EFB fiber reinforced foamcrete contributed to highest flexural strength. For example, for $800 \mathrm{~kg} / \mathrm{m}^{3}$ density, the flexural strength with $0.45 \%$ fiber inclusion by volume is $0.36 \mathrm{MPa}$ which is $40 \%$ higher than control foamcrete. The increased amount of EFB fiber added to the mix proportions (beyond $0.45 \%$ by volume) resulted in a lower flexural strength of fiber cement products.

2. $0.45 \%$ EFB fiber reinforced foamcrete also contributed to highest axial compressive strength. Inclusion of EFB fiber aid in precluding the promulgation of cracks in the plastic state in the cement matrix when load was applied.

3. When lightweight foamed concrete expands under axial compression load which will lead to cracking, the crack has a restricted distance over which it can spread before reaching the EFB fiber, preventing the crack from growing further. EFB fibers which 
were arbitrarily distributed in the mix provide three dimension reinforcement in the cement matrix.

4. Comparable trend was obtained by performance index, where the performance index is directly proportional to the specimen's curing age.

5. This study shows that natural EFB fibers have the potential to be used as strengthening materials for existing structures, such as concrete, lightweight foamcrete and masonry. In addition, the EFB fibers strengthening foamcrete has the potential for construction applications such as slabs, composite panel and deckings. .

The authors are grateful for the financial assistance of this research granted by Ministry of Higher Education Malaysia under FRGS Grant (Ref. No. 203/PPBGN/6711514)

\section{References}

1. R. C. Valore, ACI J. Proc., 50(6), 817-836 (1954)

2. S. Van Deijk, BCA, Blackwater, UK (1992)

3. H.R. Shah, J. Weiss, Mater. Struct. 9(39), 887-899 (2006)

4. E.P. Kearsley, P.J. Wainwright, Cem. Concr. Res., 32, 241-246 (2002)

5. M.A.O. Mydin, Int. J. Tech., 8(5), 800-810 (2017)

6. B. Mas, A Cladera, T.D. Olmo, Const. Bldg. Mater., 27, 612-622 (2012)

7. M.A.O. Mydin, N. Utaberta, Int. J. Appl. Eng. Res., 10(17), 37846-37850 (2015)

8. A. Kudyakov, I. Prishepa, M. Tolchennikov, IOP Conf. Series: Mater. Sc. Eng. 71, 012016 (2015)

9. A. O. Mydin, S. Soleimanzadeh, Adv. Appl. Sci. Res. 3(5), 2837-2846 (2012)

10. M.A. Othuman Mydin, J, Teknol., 78(5), 477-482 (2016)

11. G. Yakovlev, J. Kerienè, A. Gailius, I. Girnienè, Mater. Sci., 12(2), 147-151 (2006)

12. J. Zhou, S. Bai, C. Bian, Appl. Mech.Mater., 513-517, 16-19 (2014)

13. Othuman Mydin, M.A., J. Teknol., 78(5), 413-419 (2016)

14. E.K. Kunhanadan Nambiar, K. Ramamurthy, Cem. Concr. Res., 37, 1341-1347 (2007)

15. Othuman Mydin, M.A., J. Teknol., 78(5), 431-435 (2016)

16. A.H. Ameer, H.T. Nicholas, R.D. Andrew, IACSIT Int. J. of Eng. Tech, 7(4), 286-293 (2015)

17. J.M. Chi, R. Huang, C.C. Yang, J.J. Chang, Cem. Concr. Compos., 25, 197-205 (2003)

18. M.A. Othuman Mydin, N.M. Noordin, N. Utaberta, M. Y. Mohd Yunos, S. Segeranazan, J. Teknol., 78(5), 99-105 (2016) 